http://dx.doi.org/10.12775/szhf.2019.021

Krzysztof KościuszKo

Uniwersytet Warmińsko-MaZurski, Olsztyn, Polska

ORCID: 0000-0003-4474-288

E-MAIL: LOISLOIS@INTERIA.PL

\title{
Monadologia Stanisława Ignacego Witkiewicza wobec filozofii analitycznej Bertranda Russella
}

Zdaniem Bertranda Russella filozof analityczny musi być wyćwiczony w metodycznym wątpieniu, mieć zdolność sprowadzania złożonych całości do elementów prostszych (być analitykiem) oraz stosować logikę do rozwiązywania zagadnień filozoficznych. Brytyjski analityk był przekonany, że stosowanie logiki wprowadzi filozofię na zupełnie nowe tory, wierzył w jej niezwykłą płodność ontologiczną ${ }^{1}$. Jak jednak logika, względnie logiczna analiza, może być płodna ontologicznie? Początkowo w badaniach matematycznych (w Principia Mathematica) Russell szukał logicznych (tylko logicznych) atomów i tę „atomowość” odnalazł pod postacią pierwotnych pojęć logicznych i pierwotnych aksjomatów stanowiących podstawę konstrukcji całego gmachu matematyki, ale nawet $\mathrm{w}$ tym dziele znaleźć można zasady ontologiczne (a więc nie tylko logiczne), bez których Russellowi nie uda-

\footnotetext{
${ }^{1}$ Bertrand Russell, Our Knowledge of the External World (London: George Allen, 1922), 59.
} 
łoby się zrealizować założeń logicyzmu. Poza tym okazało się, że logicznie ugruntowana matematyka - jako zbiór tautologii - niczego nam nie mówi o rzeczywistym świecie. Jeśli analiza logiczna w swym działaniu pozamatematycznym miałaby nam powiedzieć cokolwiek o świecie, to na pewno musiałaby posiadać wymiar ontologiczny, powinna ustalać atomowe składniki rzeczywistości. A więc Witkacy miał rację, powątpiewając w ontologiczną płodność czystej analizy logicznej. Czysta logika może być płodna logicznie, ale nie ontologicznie czy metafizycznie. Jaki więc był stosunek Witkacego do analizy? Krytykował metody analityczne, jeśli paraliżują zdolność do syntezy, ale stawiał pod znakiem zapytania wartość wielkich syntez filozoficznych, jeśli były zbudowane na niepoprawnych wnioskowaniach logiczno-analitycznych. Chodzi o to, aby umiejętnie łączyć analizę z syntezą i na odwrót. Analizę redukcyjną powinno się uzupełnić perspektywą holistyczną.

Według Witkacego nie da się do końca skonstruować monad (poszczególnych istnień) $\mathrm{z}$ danych zmysłowych, bo monada nie jest tylko i wyłącznie treścią przeżyć psychicznych (jest możliwa jedynie częściowa konstrukcja materii biologicznej z danych zmysłowych). W ogóle trzeba odróżnić przedmiot doznania od jego treści i od samego doznania. Otóż można sprowadzać pojęcie materii (także pojęcie zmonadyzowanej materii biologicznej), względnie ducha, do danych zmysłowych jako wrażeniowych treści, ale nie powinniśmy - uważał Witkacy - zapominać o tym, że przedmiot tych treści zawsze je transcenduje. Materia może się prezentować jako to, co dane w odczuciach (jako kompleks „jakości” czy też „danych zmysłowych”), ale odebrane zmysłowo informacje nie są tym samym, czym jest odczuta materialna przedmiotowość.

Czym jest materia sama w sobie? Czy rzecz fizykalna jest jedynie konstrukcją danych zmysłowych? Witkiewicz do pewnego stopnia akceptował psychologizm (fenomenalizm), tzn. uważał, że wyrażenie pojęć i praw fizyki w języku zmysłów („jakości” w terminologii Witkiewicza) jest procederem wykonalnym, ale czy fizykalna materia jest jedynie zbiorem danych zmysłowych? Same atomy, elektrony i protony są na pewno „czymś więcej” aniżeli układami wrażeniowych treści (choćby dlatego, że cząstki elementarne nie 
muszą być dane w naoczny sposób), ale czy z metafizycznego punktu widzenia jest jeszcze „coś więcej” niż tylko martwe cząstki fizyki?

Witkiewicz miał dwojaki stosunek do języka fizyki. Z jednej strony sprowadzał go - i w tym niewiele różnił się od Russella - do języka psychologii (do tzw. danych bezpośrednich). Z drugiej strony - ponieważ ten redukcjonizm nie rozwiązywał problemu określenia stosunku materii martwej do żywej, a on sam znalazł argumenty na odrzucenie abiogennych teorii powstania biologicznego życia na Ziemi - proponował sprowadzenie języka fizyki do języka monadologii biologicznej, bo tylko synteza psychologizmu z monadologią biologiczną miałaby odzwierciedlać metafizyczną prawdę o bycie w sobie i dla siebie. Witkiewicz akceptował język fizyki, ale tylko jako przybliżony opis głębszych struktur monadycznych, gdyż da się jakoś wyjaśnić powstanie materii martwej (fizykalnej) z żywej, ale czy materia żywa mogła powstać z martwej? Niemożliwe! Witkacy uważał, że życie może powstać tylko z życia. Proponuje więc upsychologicznienie i zmonadyzowanie fizyki, natomiast Russell czasami ograniczał się (przynajmniej we wczesnej fazie swej twórczości) do psychologistyczno-fenomenalistycznej interpretacji tego, co fizyka ma nam do powiedzenia o materii martwej, a czasami lawirował między językiem fenomenalistycznym a językiem fizyki. Na stronie 118 Naszej wiedzy o świecie zewnętrznym ${ }^{2}$ powiada np., że „rzeczy to ciągi wyglądów, które przestrzegają praw fizyki" - prawa biologii nie interesują brytyjskiego analityka, problem stosunku materii martwej do żywej dla niego nie istnieje.

Kiedy Russell w dziele Nasza wiedza o świecie zewnętrznym prezentuje przedmioty fizyczne jako konstrukcje logiczne z danych zmysłowych, to zapewne realizuje swoją logiczną odmianę fenomenalizmu (a raczej odmianę tego, co sprawiało wrażenie fenomenalizmu), ale jego celem jest także budowanie pomostu między fizyką a tymi danymi. Russell dopasowuje fenomenalizm (jeśli można tak to nazwać) do odkryć dawnej i współczesnej mu fizyki. Kiedy np. definiuje rzecz nie jako trwałą substancję, lecz jako układ wyglądów, skojarzenia z teorią względności narzucają się same. Przecież w szczególnej

\footnotetext{
${ }^{2}$ Bertrand Russell, Nasza wiedza o świecie zewnętrznym (Warszawa: Altaya, 2000), 118.
} 
i ogólnej teorii względności rozmiary przedmiotów ulegają ciągłym zmianom; przestrzenny wygląd danej rzeczy zmienia się wraz ze zmianą, z której dokonuje się pomiarów. Przedmioty kurczą się albo przestrzennie rozciągają zależnie zarówno od tego, z jaką prędkością porusza się dany układ obserwująco-mierzący, jak i od prędkości samego namierzanego układu. Weźmy przykład mechaniki kwantowej: zgodnie z jej założeniami dany obiekt jest superpozycją stanów, np. superpozycją stanów położeniowych. Nie da się powiedzieć, że dany obiekt ma trwałe położenie - ma on raczej tyle położeń, ile jest aktów obserwacji. W interpretacji kopenhaskiej powiada się nawet, że dana cząstka elementarna w ogóle nie posiada położenia, jeśli nie jest namierzana. Zwróćmy uwagę na zasadę nieoznaczoności Heisenberga. Twierdzi się w niej, że jeśli np. dokładnie namierzymy energię cząstki, to niezbyt ściśle wiemy, gdzie ta cząstka się znajduje i na odwrót. Sama cząstka porusza się w sposób kwantowy, a więc znów mamy do czynienia $\mathrm{z}$ wymieniającymi się konfiguracjami treści wrażeniowych (konfiguracjami wyglądów), a nie z jakimiś trwałymi własnościami. Według Russella coś takiego jak trwała rzecz o zmiennych wyglądach w ogóle nie istnieje. Realne są jedynie wymieniające się wyglądy, czyli konfiguracje danych zmysłowych ${ }^{3}$. I brytyjski filozof ma poniekąd słuszność. Z punktu widzenia Witkacego jest to jednak racja tylko częściowa, bo jeśli mówimy o rzeczy jako układzie, względnie ciągu danych zmysłowych, to aby rozwiązać ontologiczno-metafizyczny problem stosunku materii martwej do żywej, musielibyśmy odróżnić ciągi (układy) danych zmysłowych odpowiadających materii martwej od ciągów odpowiadających materii żywej i zastanowić się, które układy danych są pierwotne. A więc można by wyrazić (i powinno się to zrobić) problem stosunku materii martwej do żywej w języku fenomenalistyczno-psychologistycznym, ale czy samo to zbliża nas choćby o krok do jego rozwiązania? Czy argumenty psychologistyczno-fenomenalistyczne, względnie fizykalistyczne, są wystarczające? Czy nie trzeba by tu sięgnąć do argumentów biologicznych?

$Z$ perspektywy Witkacego ostatecznym elementem świata nie może być żadna informacja zmysłowa ani ich kombinacja, bo są one jedynie niesamodzielnymi momentami przedmiotów materialnych, które także nie mogą reprezentować bytu w sobie i dla siebie (momentu świadomości i samoświa-

\footnotetext{
${ }^{3}$ Russell, Nasza wiedza, 99.
} 
domości) - chyba że te przedmioty będą albo samymi biologicznymi monadami, albo elementami złożonymi z materialno-biologicznych monad zdolnych do odczuwania zarówno swego własnego (w introspekcji), jak i zewnętrznego istnienia. Witkiewicz oczywiście nie był psychologistą (fenomenalistą) w stylu Ernsta Macha, ale w momentach, kiedy Russell (tak jak Mach) ujmuje dość trafnie fizykę w perspektywie psychologistycznej, wtedy sporo tez Witkiewicza pokrywa się z twierdzeniami Russella. A jest tak dlatego, że Witkiewicz, krytykując pewne formy psychologizmu, nie odrzucał go całkowicie, tj. nie odrzucał np. psychologizmu Hansa Corneliusa, względnie własnego „poprawionego psychologizmu”; ten „poprawiony psychologizm” uważał za bardzo istotny składnik swego systemu filozoficznego, ukazujący połowę prawdy o istnieniu: drugą połowę prawdy jego zdaniem odkrywała biologia, a nie fizyka (bo ani fizyka, ani fizyko-chemia nie są w stanie wyjaśnić genezy życia na kuli ziemskiej i rozwiązać problemu stosunku materii martwej do żywej). Witkiewicz jako metafizyk wychodził od faktu istnienia biologicznych monad oraz ich przeżyć (doznań). Jakości doznawane w przeżyciach stanowiły dla niego punkt wyjścia budowy psychologistycznej komponenty swego systemu.

Russell w pracy Our Knowledge of the External World także jest po części psychologistą, gdy za jedynie realne uznał tylko dane zmysłowe, z których nasz umysł konstruuje np. relacje czasoprzestrzenne. Według Witkacego tego typu konstrukcje są całkiem uzasadnione, ale autor Zagadnienia psychofizycznego nie zgadzał się, że zarówno wszechogarniająca przestrzeń, jak i wszechogarniający czas miałyby być ontycznymi fikcjami. Russell nie zgadza się, że istnieje jedna wszechogarniająca przestrzeń, której fragmentami byłyby przestrzenie lokalne ${ }^{4}$ ani że istnieje jeden wszechogarniający czas zawierający wszystkie możliwe czasy prywatne. Filozof w swej redukcyjnej analizie niewątpliwie chciał uwzględnić odkrycia szczególnej i ogólnej teorii względności Einsteina i budować pomost między fizyką a danymi zmysłowymi. Prym wiodła fizyka, a ponieważ Albert Einstein wyraził wątpliwości co do istnienia jednej wszechogarniającej przestrzeni ${ }^{5}$, filozofia powinna brać to pod uwagę. Problem w tym, że nieistnienie jednej wszechogarniającej

\footnotetext{
${ }^{4}$ Russell, Nasza wiedza, 112.

${ }^{5}$ Russell, Nasza wiedza, 112.
} 
przestrzeni nie jest takie pewne z naukowego punktu widzenia. Sam Witkiewicz, chociaż akceptował względność przestrzeni, nie rezygnował z sensowności posługiwania się pojęciem przestrzeni absolutnej. Piszę o tym szerzej $\mathrm{w}$ artykule pt. Witkacy uwikłany w spór między absolutna a relacyjna teoria przestrzeni ${ }^{6}$. Do dzisiaj fizycy nie mogą pozbyć się pojęcia przestrzeni służącej jako uniwersalne i niezależne tło dla dynamiki cząstek elementarnych. Nawet teoria strun jest uzależniona od statycznej przestrzeni, w której geometria nie zmienia się $\mathrm{w} \mathrm{czasie}^{7}$. Czyż więc nie lepiej - z punktu widzenia Witkacego - traktować teorie naukowe jako tymczasowe hipotezy robocze, a nie jako ostateczne prawdy o materii? Witkacy nie podporządkowywał filozofii nauce (jak Russell). Teorie naukowe traktował, jakby były to jedynie wstępne koncepcje. I starał się znaleźć dla nich miejsce w swojej ontologii, nie preferując żadnej z nich.

Albo weźmy pojęcie czasu: dla Russella intersubiektywny, wszechogarniający czas jest fikcją z punktu widzenia zarówno fizyki, jak i ontologii, bo przecież teoria względności skrytykowała tego rodzaju ujęcie czasu ${ }^{8}$. Ale czy istotnie rozwój nauki w sposób jednoznaczny opowiedział się po stronie destrukcji pojęcia wszechobejmującego czasu? Przecież np. Lee Smolin dowodzi, że hipoteza realności globalnego czasu prowadzi do bardzo wartościowych kosmologii i że pojęcie czasu realnego i globalnego jest pomocne w rozwiązywaniu wielu problemów fizyki ${ }^{9}$. Przewiduje on zresztą, że niedługo w kosmologii i w fizyce zwyciężą programy badawcze oparte na pojęciu globalnie uczasowionego wszechświata.

Według Russella nie wiemy, czym są same w sobie atomy, protony, elektrony i jeszcze drobniejszego rzędu cząstki elementarne. Znamy jedynie sieć (strukturę) oddziaływań przyczynowych między nimi, ale niewiele wiemy o ich wewnętrznej naturze. Czy podobnie rzecz ma się z mózgiem? Czym

\footnotetext{
${ }^{6}$ Krzysztof Kościuszko, „Witkacy uwikłany w spór między absolutną a relacyjną teorią przestrzeni”, Rocznik Podhalański XI (2016): 321-336.

${ }^{7}$ Lee Smolin, Kłopoty z fizyka (Warszawa: Pruszyński i S-ka, 2008), 192-198.

${ }^{8}$ Russell, Nasza wiedza, 131.

${ }^{9}$ Lee Smolin, Czas odrodzony (Warszawa: Prószyński i S-ka, 2015), 326.
} 
jest mózg sam w sobie? Czy jest tylko szarą substancją przypominającą kalafior? Czyż nie jest raczej złożoną strukturą neuronalną, względnie całością neuronalnych procesów przyczynowo-skutkowych? Z pewnością z punktu widzenia neurofizjologa mózg jest właśnie tym; ale czym jest mózg dla psychologa? Czyż nie jest on powiązany ze stanami psychicznymi danymi w introspekcji? Odpowiedź jest oczywista, ale czy to możliwe, aby poznawczo pierwotne (bezpośrednio dane) stany psychiczne stanowiły też wewnętrzną istotę (rozumianą ontycznie) neuronalnych zdarzeń? Zdawać by się mogło, że stany psychiczne nie są stanami neuronalnymi, ale Russell twierdzi, że są one tożsame z wewnętrzną istotą stanów neuronalnych, i m.in. w ten sposób rozwiązuje problem psychofizyczny. Jak to jednak możliwe, aby zdarzenia neuronalne były tożsame ze zdarzeniami psychicznymi?

Otóż to, co fizyczne, nie może być przyczyną tego, co psychiczne (tego, co niefizyczne). Nie jest możliwe, aby na końcu czysto fizycznego łańcucha zdarzeń (np. przebiegu fal elektromagnetycznych) mogło się pojawić zdarzenie mentalne, $\mathrm{np}$. wrażenie czerwieni ${ }^{10}$. Albo: $\mathrm{z}$ impulsów elektrycznych przebiegających neurony nie otrzymamy procesów psychicznych. Ale jeśli materia mózgowa jest zbiorem neutralnych zdarzeń ${ }^{11}$, ani fizycznych, ani psychicznych, inaczej mówiąc: zbiorem zdarzeń częściowo fizycznych, częściowo psychicznych, to stosunek duszy do ciała da się zrozumieć jako stosunek zdarzeń mentalno-fizycznych (tego, co tradycyjnie ujmuje się jako procesy psychiczne) do zdarzeń fizyczno-mentalnych (do tego, co tradycyjnie uchodzi za proces mózgowy). Zdarzenie fizykalne wywołujące dane wrażenie barwne wcale nie jest do końca fizykalne, bo gdyby było, nie doprowadziłoby do pojawienia się niefizycznego wrażenia, a więc fizykalne bodźce są w gruncie rzeczy bodźcami fizykalno-mentalnymi. Dusza oddziałuje na ciało, bo zdarzenia mentalne są częściowo zdarzeniami fizyczno-neuronalnymi. Jeśli zdarzenia są częściowo fizyczne, a częściowo psychiczne, to znaczy, że nie są w całości ani fizyczne, ani psychiczne, a więc są neutralne (są mieszanką fizyczności z psychicznością).

\footnotetext{
${ }^{10}$ Bertrand Russell, Analysis of Matter (London: Routledge, 1992), 275.

${ }^{11}$ Termin „zdarzenie neutralne” użyty jest w znaczeniu „zdarzenie posiadające nieokreślony charakter", zdarzenie pośrednie między zdarzeniem fizykalnym i mentalnym.
} 
Czym stanowisko Russella różni się od podejścia Witkacego, który przecież także utożsamił duszę z ciałem i umysł z mózgiem? Odmienność Witkiewiczowskiego myślenia polega na tożsamości w różnicy: choć dusza różni się od ciała (a psychika od mózgu), jest z nim tożsama, bo dusza (umysł) jest samoodczuwaniem ciała (mózgu). Natomiast Russell chce nas przekonać, że mózg i umysł są jednorakie, bo niczym się nie różnią: to, co psychiczne, jest tym, co fizyczne, i na odwrót. Według brytyjskiego analityka zdarzenia fizyczne (np. neuronalne) są zdarzeniami mentalnymi, bo m.in. $\mathrm{w}$ procesie patrzenia zewnętrzny bodziec fizykalny przechodzi w neuronalno-fizyczny bodziec wzrokowy, a ten z kolei wywołuje w mózgu fizykalne reakcje, do których można zaliczyć np. wzrokową treść wrażeniową, a więc coś mentalnego. Jak to możliwe, aby coś fizycznego przeobraziło się w coś mentalnego? Chyba tylko dzięki temu, że istność mentalna byłaby zarazem istnością fizykalną. Russell nie jest fizykalistą: nie twierdzi, że zdarzenia mentalne są redukowalne do zdarzeń fizykalnych. Chce raczej powiedzieć, że istności fizyczne są upsychicznione, bo gdyby nie były, nie doszłoby np. do odpowiedzi ciała (względnie mózgu) na przeżycia psychiczne. Witkacy ujął to tak: czucie (percepcja) składa się według Russella z elementów fizycznych, czyli np. elektrony w mózgu są pomieszane $z$ percepcjami ${ }^{12}$. Witkacy uważał zaś, że czucie (percepcja) nie może składać się z elementów fizykalnych, bo czucia (percepcje, zdarzenia mentalne) nie są przecież wynikiem elektrycznych impulsów. Zdarzenia elektryczne należą do jednego, a zdarzenia mentalne do innego jakościowo szeregu zdarzeń. To niemożliwe, aby percepcje i zdarzenia fizykalne stanowiły elementy tego samego (jakościowo) ciągu zdarzeń. Zdarzeniom mentalnym możemy przyporządkować zdarzenia fizykalne, ale nie da się ich utożsamić ani całościowo, ani częściowo.

Według Witkacego rozważania Russella związane z jego tezą o tożsamości mózgu i psychiki są tylko częściowo słuszne. Nie zniosły ani starego podziału na materię martwą i żywą, ani rozróżnienia na to, co fizyczne, i to, co psy-

\footnotetext{
${ }^{12}$ Stanisław Ignacy Witkiewicz, Nauki ścisłe a filozofia (Warszawa: PIW, 2014), 597.
} 
chiczne. Russell unieważnił tylko dualizm mózg-umysł. Ale czy naprawdę to zrobił? Witkacy twierdzi, że rozdział między mózgiem i umysłem można by zlikwidować, jedynie przestając traktować mózg i zdarzenia mentalne jako coś po części fizycznego i po części mentalnego. Russell wymieszał zdarzenia mentalne fizykalnymi, ale nie dowiódł ich tożsamości. Bo czy z tego, że dwie różne istności są wymieszane, wynika, że są one tożsame?

Obaj nie akceptowali panpsychizmu ${ }^{13}$, ale u Russella część materii, tzn. materia mózgowa, jest upsychiczniona; niebiologicznej materii fizycznej nie przysługiwałaby bowiem możliwość odbioru zjawisk, a więc można byłoby mówić o dualizmie. Witkacy odrzuca panpsychizm, bo trudno jest stwierdzić, że np. u elektronu budującego strukturę atomową jakiegoś „martwego przedmiotu” ukształtowały się psychika i przeżycia mentalne. Elektron nie może doświadczać przeżyć mentalnych, ale mogą one stać się udziałem (zgodnie z hipotezą monadologiczą) subelektronowych biologicznych monad, składających się na jego istnienie. Aby znieść dualizm tego, co fizyczne, i tego, co psychiczne, trzeba by, po pierwsze, uznać psychizm za atrybut nie materii fizycznej, lecz materii żywej (monadyczno-biologicznej), po drugie, przyjąć, że materia żywa jest jedyną materią egzystującą w całym wszechświecie (tj. zgodzić się, że wszelka materia fizykalna jest przejawem jakiejś pierwotnej materii biologicznej). Czyli należałoby najpierw sprowadzić całą materię fizyczną do biologicznej, a potem pokazać, że biologiczne ciało jest tożsame z przeżyciami mentalnymi na zasadzie tożsamości w różnicy: choć ciało różni się od duszy (od przeżyć mentalnych), to jednak stanowi z nim jedność; dusza jest tożsama z ciałem (biologicznym, a nie fizycznym), bo „jaźń" jest tylko samoodczuwaniem ciała, ciało zaś jest zewnętrzną ekspresją duszy (jaźni, umysłu), i właśnie to starał się udowodnić Witkacy. Obiekt fizyczny nie może mieć duszy, ale mogą ją mieć jego mikrobiologiczne składniki. W rezultacie możemy mówić o monizmie biologiczno-psychicznym Witkacego.

O ile Russell zgadzał się, że ciało = dusza (mózg = umysł), o tyle nie akceptował tego, że wszelka materia fizykalna równa się materii biologicznej. Jeśliby uznać, że cała materia fizykalna jest w gruncie rzeczy sprowadzalna do materii biologicznej, a ta ostatnia jest tożsama (na zasadzie tożsamości w róż-

\footnotetext{
${ }^{13}$ Russell, Analysis, 388.
} 
nicy) z psychizmem, wtedy dałoby się załatać dualizm tego, co fizyczne, i tego, co psychiczne. U Russella mamy tylko pseudotożsamość przeżyć mentalnych i mózgu, ale niebiologiczne przedmioty fizyczne ani nie mają ani mózgu, ani nie doświadczają przeżyć mentalnych (Russell nie był panpsychistą). Nie są też złożone z mikromonad biologicznych, którym przysługuje psychizm.

Podsumowując: u Russella przedmioty fizyczne biologiczne (np. neurony) są tożsame ze stanami psychicznymi, natomiast przedmioty fizyczne niebiologiczne nie są tożsame z tymi stanami psychicznymi. Jeśli nie ma takiej tożsamości, to doktryna Russella - wbrew jego zamierzeniom - jest filozofią połowicznej tożsamości.

Czy Witkacy był nominalistą? Chyba tylko w tym sensie, że według niego tak naprawdę istnieją jedynie przedmioty jednostkowe (monady poszczególne). Ale zauważał, że mają zarówno cechy różnicujące je między sobą, jak i cechy upodobniające do siebie, tj. pozwalające na zaklasyfikowanie danego zbioru indywidualnych przedmiotów do tego samego typu, pozwalające na utożsamienie tego, co różne. Przedmioty jednostkowe mają cechy indywidualizujące je i cechy podobne, tożsame, będące tym, co uniwersalne (powszechne). Uniwersalia istnieją więc obiektywnie i realnie jako zbiór jednostkowych tożsamości w indywidualnych różnicach, tj. jako zbiór cech wspólno-tożsamych. Można by więc powiedzieć, że Witkacy - choć nie zdawał sobie z tego sprawy - jest realistą pojęciowym, tyle że nie transcendentnym (jak np. Platon), lecz immanentnym. Uniwersalia jako cechy wspólne (mogące być treścią pojęć ogólnych) są zakorzenione w cechach materialnych przedmiotów; nie są one pozaprzestrzennymi i pozaczasowymi ideami Platona.

Czy Witkacy ma coś wspólnego z umiarkowanym nominalizmem, czyli konceptualizmem? Okazuje się, że tak. Jak to możliwe, że będąc realistą, był zarazem konceptualistą? Jest to możliwe, bo Witkacy dostrzegał źródło ogólności słów nie tylko w ontycznych cechach wspólnych indywidualnych przedmiotów, ale także w ogólnych treściach myśli. Uniwersalia istnieją także w ludzkim umyśle jako pojęcia ogólne. Witkacy nie zdawał sobie sprawy, że w jego podejściu do problemu uniwersaliów można odnaleźć elementy paru 
stanowisk. Różnił się od Russella, który co prawda deklarował się jako antymistyk, jednak sympatyzował $\mathrm{z}$ transcendentnym realizmem ${ }^{14}$. Ciekawe jest to, że choć dzieło Principia Mathematica miało być napisane z pozycji nominalistycznych, w rzeczywistości ma platoński charakter.

Witkacy bardzo ostro krytykował platoński charakter logicyzmu. Zresztą był przekonany, że sprowadzenie matematyki do logiki jest zadaniem niemożliwym do realizowania. Potwierdzili to krytycy programu logicyzmu, wykazując, że ani aksjomat nieskończoności, ani rozmaite postulaty przyjęte przez Bertranda Russella i Alfreda Whiteheada nie mają czysto logicznego charakteru ${ }^{15}$.

Platonizm Russella zakładał, że pojęciom logiczno-matematycznym odpowiadają samoistne przedmioty idealne niezależne w swej egzystencji zarówno od konkretnych przedmiotów fizycznych, jak i od matematyka mogącego je poznać ${ }^{16}$. Tak jakby matematyka nie była stwarzana, lecz wyłącznie odkrywana. Kłóci się to ze stanowiskiem Witkacego, według którego matematyka jest odkrywana, ale jest też stwarzana. Przecież matematycy ciągle manipulują przy zastanej przedmiotowości matematyki, rozwiązują problemy w różnoraki (indywidualny) sposób, dyskutują i spierają się ze sobą. Często tworzą mylne hipotezy i poprawiają je; te hipotezy wcale nie są precyzyjne i jasne; dowody nie są przekonujące. Matematyka w ogóle nie jest niepodważalna; jest dziełem spekulacji i poszukiwania alternatywnych hipotez. Dlatego Witkacy opowiadał się raczej po stronie konstruktywizmu Henriego Poincarégo, który uważał, że wszelka matematyczna przedmiotowość jest raczej podmiotowo konstruowana aniżeli przedmiotowo egzystująca w niezmiennej postaci w transcendentnych zaświatach. Akceptował postawę Poincarégo w stosunku do aktualnej nieskończoności: o ile Russell przyjmował jej istnienie i promował Cantorowskie badania teoriomnogościowe, o tyle Poincaré doradzał ograniczenie się jedynie do nieskończoności potencjalnej ${ }^{17}$. U Poincarégo Witkacy znalazł potwierdzenie tezy, że matematyki nie da się sprowadzić do

\footnotetext{
${ }^{14}$ Bertrand Russell, Zagadnienia filozofii (Warszawa: Altaya, 2002), 101.

${ }_{15}$ Thomas Bedürftig, Roman Murawski, Philosophie der Mathematik (Berlin-New York: de Gruyter, 2010), 88-89.

${ }_{16}$ Takie stanowisko zajmował Russell w The problems of Philosophy.

${ }^{17}$ Witkiewicz, Nauki ścisłe, 180-181.
} 
logiki (bo np. logicyści często robią użytek z rozumowania indukcyjnego wywodzącego się przecież z fizyki, względnie z matematyki).

Jaka jest geneza platonizmu? Zapewne poszukiwanie wiedzy absolutnie pewnej, wiedzy koniecznej. Ale czy poszukiwanie prawd koniecznych wyklucza empiryzm? Czy w obszarze empirycznej podmiotowości i empirycznej przedmiotowości nie ma koniecznych struktur? Struktur pozaczasowych? Czyżby matematyki nie dało się - choćby częściowo - wyprowadzić z praw rządzących ludzką psychiką (przecież właśnie psychologizm krytykowany przez Edmunda Husserla jest zdaniem Witkacego częściowo słuszny), ewentualnie z prawidłowości organizujących przedmiotowością empiryczną? Witkacy chciał udowodnić, że jest to możliwe (przynajmniej do pewnego stopnia) i że nie pociąga za sobą rezygnacji z koniecznościowego charakteru np. zdań matematycznych. To nie idealno-transcendentna przedmiotowość miała stanowić bazę tego, co konieczne w matematyce, lecz indywidualna przedmiotowość empiryczno-zmysłowa; przy czym nie zdawał sobie sprawy $\mathrm{z}$ tego, że jego konceptualizm (umiarkowany nominalizm) zawiera element kompromisu $\mathrm{z}$ realizmem; oczywiście nie $\mathrm{z}$ realizmem transcendentnym, lecz $\mathrm{z}$ realizmem immanentnym. Transcendentnego realizmu nie akceptował, bo nie mógł sobie wyobrazić, jak np. konkretne białe rzeczy miałyby uczestniczyć w transcendentnej bieli? Albo jak konkretne przedmioty miałyby uczestniczyć w liczbie 3? Jeśli w ogóle można mówić o uczestnictwie konkretno-zmysłowych rzeczy w jakiejś wspólnej idei, to ta wspólna idea nie może być pojęta jako coś niemającego nic wspólnego z tą konkretnością.

Zdawać by się mogło, że nie ma wielkiej różnicy między Russellem a Witkiewiczem, jeśli chodzi np. o uznanie, że relacja podobieństwa między rzeczami jest czymś uniwersalnym ${ }^{18}$. Jednak dla Witkiewicza ta uniwersalna więź podobieństwa jest jednocześnie stosunkiem niepodobieństwa; podobieństwo jest wytworem abstrakcji i uogólnienia tego, co obserwujemy w wielu konkretnych przypadkach, kiedy dostrzegamy jakąś analogię między indywidualnymi przedmiotami. Podobieństwo takie ma ontyczno-

${ }^{18}$ B. Russell, The Problems of Philosophy (London: Georg Allen \& Unwin LTD. 1912), 46. 
-materialny fundament przejawiający się $\mathrm{w}$ jednoczesnym istnieniu cech wspólnych dla tych konkretnych przedmiotów i elementów różnicujących je. Zróżnicowane są nie tylko przedmioty indywidualne, ale także rodzaje zachodzącego między nimi podobieństwa, tj. podobieństwa między relacjami podobieństwa. A więc podobieństwo między relacjami podobieństwa jest zarazem niepodobieństwem. Same podobieństwa są różnorodne, nie mogą więc egzemplifikować jakiegoś powszechnika; możliwe relacje analogii między podobieństwami nie mogą uczestniczyć w jednym (transcendującym je) powszechniku, bo różnią się od siebie - są one przecież zbliżone tylko pod jakimś względem; podobieństwo pokrewnych relacji występuje na tle niepodobieństw; nie ma podobieństw bez różnic. Nie da się oddzielić podobieństw od różnic. A jeśli tak sprawy się mają, to rzekomy powszechnik ustalający podobieństwo musiałby również określać różnice, a cóż to za powszechnik, który obok podobieństwa fundowałby niepodobieństwo?

Weźmy np. relację „na północ od”. Z perspektywy Witkacego jest ona przykładem tego, co uniwersalno-partykularne, ale nie jest ona czymś (jak u Russella) transcendentnym (pozaprzestrzennym i pozaczasowym). Jako pojęcie jest ona wyabstrahowana z konkretnych, empirycznych relacji danych obiektów względem siebie (empirycznie danych, konkretnych relacji bycia „na północ od") i zarazem jest ich uogólnieniem; ale to pojęcie nie jest wycelowane w uniwersalną ideę „bycia na północ od” (ta uniwersalność tylko pozornie jest uniwersalna). To tylko w ramach analiz Russella dane relacje sprawiają wrażenie, jakby mogły egzystować na zewnątrz obiektów pozostających w tych układach.

Co więcej, ta relacja znajdowania się „na północ od” jest w pewnym sensie zależna (w perspektywie Russella o takiej zależności nie może być mowy) od naszej aktywności mentalnej, a mianowicie od naszej zdolności do tworzenia konwencji, bo jest sprawą konwencjonalną, który kierunek przestrzeni uznamy za „północ”, a który za „południe”.

Czy powszechniki są niezmienne? Otóż według Witkacego uniwersaliom (rozumianym w sensie immanentnego realizmu skojarzonego z konceptualizmem) wcale nie przysługuje niezmienność. Weźmy np. relację „później niż”. Tego typu relacja z perspektywy teorii względności będzie rozmaicie budowana w różnych układach, czy to poruszających się z niejednakowymi prędkościami, czy to poruszających się w różnorakich polach grawitacyjnych. 
Przykładowo w świecie, w którym osiągalne byłyby prędkości ponadświetlne, skutki pewnych działań występowałyby przed ich przyczynami, a więc to, co powinno być „później”, miałby miejsce „wcześniej”. Podobnie jest z relacjami przestrzennymi. Relacja „na północ od” będzie miała inny sens dla różnych obserwatorów poruszających się z odmiennymi prędkościami.

Z punktu widzenia Russella w świecie empirii nie da się odnaleźć związków pozaczasowych i koniecznych (twierdzenia nauk empirycznych - w przeciwieństwie do np. twierdzeń matematyki - są niepewne), natomiast z perspektywy Witkacego problem konieczności i niezmienności wyglądał inaczej, bo według autora Zagadnienia psychofizycznego w obszarze materii empirycznej da się jednak odnaleźć związki konieczne. Nie są to oczywiście konieczności absolutne, ale gdzie miałyby przebywać absolutne prawdy o niezmiennych i koniecznych relacjach? Czyżby w świecie matematyki? Otóż Witkacy twierdził, że nawet prawdom logiczno-matematycznym nie przysługuje absolutna konieczność.

Russell uważał, że wszelka wiedza a priori (w tym wiedza matematyczna) zajmuje się relacjami między powszechnikami. $Z$ tym twierdzeniem można się zgodzić bądź nie -wszystko zależy od tego, jak rozumiemy powszechniki. Jeśli powszechniki jako przedmioty ogólne oznaczałyby spartykularyzowane uniwersalia istniejące $\mathrm{w}$ danej zbiorowości podobnych do siebie przedmiotów, to powyższa teza brytyjskiego myśliciela dałaby się uzgodnić ze stanowiskiem Witkiewicza. Ponieważ jednak u Russella powszechniki zdają się oznaczać relacje transcendentne (tzn. relacje istniejące na zewnątrz świata rzeczy) ${ }^{19}$, więc nie ma tutaj możliwości uzgodnienia. Według Witkacego powszechniki istnieją w świecie pojęć jako ogólne sensy i znaczenia, jako twory i wytwory świata kultury powiązane z konkretnymi znakami, a odnoszą się nie do jakiejś pozakonkretnej rzeczywistości, lecz do cech (i relacji) realnego świata (cechy i relacje nie mogą istnieć poza obiektami funkcjonującymi w ramach tych relacji); są wytwarzane w procesach idealizacji, abstrakcji i uogólnienia. Jak każdy twór kultury, powszechniki potrzebują do swego istnienia zarówno aktywności wielu podmiotów, jak i zakorzenienia w świecie materialnym. W swym byciu powszechniki są uzależnione od aktów uogólniania - są więc konstruowane, ale są też „odkrywane”, tak jak wciąż odkrywamy nowe relacje

${ }^{19}$ Tak myśli Russell w The Problems of Philosophy. 
między pojęciami (znaczeniami). To odkrywanie nie dokonuje się - twierdził Witkacy - poprzez akty wglądu w odwieczny świat znieruchomiałych idei (istniejących na zewnątrz konkretnych obiektów), lecz poprzez ciągłe konfrontowanie pojęciowej wiedzy $\mathrm{z}$ wciąż niepoznanymi do końca strukturami empiryczno-materialnego świata.

Jeśli powszechniki miałyby znajdować się poza rzeczami i poza konkretnymi relacjami (powszechnik „nie jest ani w czasie, ani w przestrzeni”20), to ich związek z konkretno-zmysłową przedmiotowością (relacyjnością) staje się problemem.

Czyżby więc dla Witkacego twierdzenia logiczno-matematyczne były tylko „empirycznymi uogólnieniami”? Jak to pogodzić z jego przekonaniem, że tym twierdzeniom przysługuje jednak aprioryczny charakter (tzn. mogą być dziełem rozumu, a zarazem są konieczne i powszechne)? Dlaczego jednak takie empiryczne a priori miałoby być czymś niemożliwym? Dlaczego empiryczne uogólnienie nie miałoby być efektem pracy intelektu (oczywiście nie chodzi tu o „intelekt” w rozumieniu Immanuela Kanta) i zarazem nie miałoby być powszechne i konieczne? Nie chodzi tu przecież o konieczność w znaczeniu absolutnej konieczności.

Według Russella w przypadku empirycznych uogólnień uzasadnienia danych twierdzeń są indukcyjne, natomiast w przypadku apriorycznych twierdzeń matematyki procedurą uzasadniającą (dowodzącą) miałoby być dedukcyjne wywodzenie jednych matematycznych powszechników z drugich. Wszelkie zdania matematyki można byłoby wywieść z logicznych definicji i aksjomatów, ale matematyka koncypowana w tego typu logicystycznej perspektywie nabiera syntaktyczno-tautologicznego charakteru; relacja matematyki do empirycznego świata staje się czymś niejasnym.

Ponieważ jednak matematykę można - jak uważał Witkacy - zastosować do opisu zmysłowych faktów, więc nie może ona mieć czysto aprioryczno-syntaktycznego charakteru. Jest ona raczej jednocześnie czymś a priori i a posteriori. Sam Russell zmieniał zresztą dość często swe poglądy i w końcu uznał, że to, co a priori (analityczne), może jednocześnie być a posteriori, tzn. że syntaktyczno-tautologiczny język matematyki może jednak odzwierciedlać

\footnotetext{
${ }^{20}$ Russell, Zagadnienia, 101.
} 
empiryczny świat ${ }^{21}$. W jakim sensie? Mianowicie w takim, że chociaż zdania matematyki są tautologiami i nie dostarczają nam wiedzy o przedmiotowości pozamatematycznej, a jeśli przekazują jakieś informacje, to raczej o naszym sposobie mówienia o tej przedmiotowości, to jednak analizując matematyczny sposób mówienia o świecie (tzn. analizując definicje symboli użytych w danym języku matematycznym i reguły posługiwania się nimi), możemy dowiedzieć się czegoś także o samej faktycznej strukturze tego świata.

Witkacy zapewne zaakceptowałby to późniejsze stanowisko Russella, który poprzez badanie syntaksy (w tym matematyki jako syntaksy języka nauki) chciał zdobywać wiedzę o strukturze świata. Takie ontologizowanie syntaksy było zgodne z jego (Witkacego) programem ontologizowania logiki i matematyki.

\section{Bibliografia}

Bedürftig Thomas, Murawski Roman. 2010. Philosophie der Mathematik. Berlin-New York: de Gruyter.

Kościuszko Krzysztof. 2016. „Witkacy uwikłany w spór między absolutną a relacyjną teorią przestrzeni”. Rocznik Podhalański 11: 321-337.

Russell Bertrand. 1912. The Problems of Philosophy. London-New York.

Russell Bertrand. 1922. Our Knowledge of the External World. London: George Allen. Russell Bertrand. 1992. Analysis of Matter. London: Routledge.

Russell Bertrand. 1995. Inquiry into Meaning and Truth. London: Routledge.

Russell Bertrand. 2000. Nasza wiedza o świecie zewnętrznym. Warszawa: Altaya.

Russell Bertrand. 2002. Zagadnienia filopzofi. Warszawa: Altaya. Smolin Lee. 2008. Kłopoty z fizyką. Warszawa: Pruszyński i S-ka. Witkiewicz Stanisław Ignacy. 2014. Nauki ściste a filozofia. Warszawa: PIW.

\footnotetext{
${ }^{21}$ Bertrand Russell, Inquiry into Meaning and Truth (London: Routledge, 1995), 341-347.
} 


\section{Abstract \\ Monadology of Stanisław Ignacy Witkiewicz in the face of Bertrand Russell's philosophy}

In the article I intend to reconstruct Witkacy's standpoint in relation to Russell's philosophy; it will not concern the whole philosophy of the British analyst, but only the area which was a subject of Witkacy's study. These studies have not got a finished, completed form because they were either printed out of manuscripts devastated during World War II or they constitute fragmentary reflexions. I present Witkiewicz's critical attitude toward the following ideas: the idea of a philosophical analysis, the idea of the psyche and brain identity and the idea of neutral monism. As far as the issue of universals is concerned, I distinguish Witkiewicz's immanent realism from Russell's transcendent realism. I indicate a similar attitude of the two thinkers to the ontology of mathematics.

Keywords: analysis; identity theory; monadology; neutral monism; nominalism; ontology; panpsychism; phenomenalism; Platonism; syntax; theory of relativity; universals.

\section{Streszczenie}

\section{Monadologia Stanisława Ignacego Witkiewicza wobec filozofii analitycznej Bertranda Russella}

W artykule rekonstruuję stanowisko Witkacego wobec filozofii Russella; oczywiście nie dotyczy to całej filozofii brytyjskiego analityka, lecz tylko tej jej części, która była przedmiotem rozmyślań Witkacego. Te przemyślenia nie mają ukończonej formy, ponieważ albo wydrukowane zostały ze zniszczonych przez drugą wojnę światową rękopisów, albo stanowią fragmentaryczne refleksje. Prezentuję krytyczne stanowisko Witkiewicza w stosunku do idei filozoficznej analizy, idei tożsamości mózgu i psychiki, idei monizmu neutralnego. W kwestii uniwersaliów odróżniam immanentny realizm Witkiewicza od transcendentnego realizmu Russella. Sygnalizuję podobny stosunek obu myślicieli do ontologii matematyki.

Słowa kluczowe: analiza; fenomenalizm; monadologia; monizm neutralny; nominalizm; ontologia; panpsychizm; platonizm; uniwersalia; syntaksa; teoria identyczności; teoria względności. 